\title{
Evaluation of Clinical and Laboratory Data of Pediatric Patients Diagnosed with Infectious Mononucleosis
}

\section{Enfeksiyöz Mononükleoz Tanısı Alan Çocuk Hastaların Klinik ve Laboratuvar Verilerinin Değerlendirilmesi}

Hayrettin Temel ${ }^{1}$,

Mehmet Gunduz ${ }^{1}$

${ }^{1}$ Istanbul Medipol University, Faculty of Medicine, Department of Pediatrics, Istanbul, Turkey.

Geliş Tarihi/Received: 2 May 2020 Kabul Tarihi/Accepted: 23 June 2020

Address correspondence to: Hayrettin Temel, Istanbul Medipol University, Faculty of Medicine, Department of Pediatrics, Istanbul, Turkey.

e-mail: hayrettintemel@hotmail.com

\section{ORCID}

Hayrettin Temel

https://orcid.org/0000-0002-6490-4530

Mehmet Gunduz

https://orcid.org/0000-0003-1735-4318

\begin{abstract}
Öz
Amaç: Çocukluk döneminde Epstein-Barr virüsü (EBV) nedenli enfeksiyöz mononükleoz olguları yüksek sıklıkta görülmektedir. Akut EBV enfeksiyonu belirti ve bulguları farklı klinik tablolarla kendini gösterebilmektedir. Çalışmamızda çocuklar arasında yaş ve yüksek riskli yaş gruplarına göre akut EBV enfeksiyonlarının klinik sunumunun incelenmesi amaçlandı.

Hastalar ve Yöntem: Çalışmaya 2013-2020 yıllarında üçüncü basamak hastanemize başvuran ve enfeksiyöz mononükleoz tanılı toplam 337 çocuk hasta dahil edildi. EBV VCA IgM ve IgG antikorları ELISA yöntemiyle (quantitative microplate ELISA, Euroimmun ${ }^{\circledR}$, Almanya) firma önerileri doğrultusunda çalışıldı. Hasta bilgileri ve sonuçları retrospektif olarak değerlendirildi.

Bulgular: Hastaların ortalama yaşı 5.1 \pm 3.4 yıl idi. Hastaların \%22.8'si 0-2, \%43.0'i 3-5, \%29.7'si 6-12, $\% 4.5$ ' $\mathrm{i}$ ise 12 yaş ve üzeri gruptaydı. Akut EBV enfeksiyonu tanısı konulan çocuklarda en sık görülen belirti veya bulgular lenfadenopati (\%59.6), lenfositoz (\%45.1), ateş (\%40.9), boğazda şişlik (\%39.2) ve farenjit (\%30.0) idi. Ateş şikayeti, 3-5 yaş arasında diğer yaş gruplarına göre anlamlı yüksekti $(p=0.003)$. Olguların mevsimsel dağılımı benzerdi. Olguların yıllara göre artış içinde olduğu, en çok olgunun 2019 yılında görüldüğü $(\% 23.4)$ belirlendi. Şikayetlerin başlamasından hastaneye başvuru yapılana kadar geçen sürenin yaş grupları ile doğru orantılı olarak artı̆ğı görüldü.

Sonuç: Çalışmamızda akut EBV enfeksiyonunda çocukluk dönemi yaş grupları arasında belirti ve bulgular açısından farklılık olmadığı, yıllara göre olgu sayılarının hafif bir artış içinde olduğu, özellikle enfadenopati, splenomegali ve hepatomegali görülen çocuklarda EBV enfeksiyonundan şüphe etmek gerektiği sonucna varıldı.

Anahtar Kelimeler: Epstein-Barr virüsü, enfeksiyöz mononükleoz, çocuk, EBV VCA IgM.

\section{Abstract}

Aim: In childhood, infectious mononucleosis cases caused by Epstein-Barr virus (EBV) are seen with high frequency. The signs and symptoms of acute EBV infection can manifest with different clinical pictures. Care should be taken in differential diagnosis for correct treatment. In our study, it was aimed to examine the clinical presentation of acute EBV infections by age and high-risk age groups among children.

Patients and Methods: A total of 337 pediatric patients with infectious mononucleosis who applied to our tertiary hospital in 2013-2020 were included in the study. EBV VCA IgM and IgG antibodies were studied by ELISA method (quantitative microplate ELISA, Euroimmun ${ }^{8}$, Germany) in accordance with company recommendations. Patient information and results were evaluated retrospectively.

Results: The mean age of the patients was $5.1 \pm 3.4$ years. $22.8 \%$ of the patients were in the group of $0-2$ $43.0 \%$ of them were $3-5,29.7 \%$ of them were $6-12$, and $4.5 \%$ of them were 12 years old and above. The most common signs or symptoms in children diagnosed with acute EBV infection were lymphadenopathy $(59.6 \%)$, lymphocytosis $(45.1 \%)$, fever $(40.9 \%)$, swelling in the throat $(39.2 \%)$ and pharyngitis $(30.0 \%)$. Fever complaints were significantly higher between the ages of 3-5 compared to other age groups. The seasonal distribution of the cases was similar. It was determined that the cases increased over the years and the most cases were seen in $2019(23.4 \%)$. It was observed that the time between the start of complaints and the application to the hospital increased directly proportional to age groups.

Conclusion: In our study, it was concluded that there was no difference in acute EBV infection in childhood age groups in terms of signs and symptoms, and the number of cases increased slightly over the years, especially in children with lymphadenopathy, splenomegaly and hepatomegaly.
\end{abstract}

Key words: Epstein-Barr virus, infectious mononucleosis, child, EBV VCA IgM
Cite this article as: Temel $\mathrm{H}$, Gunduz M. Evaluation of Clinical and Laboratory Data of Pediatric Patients Diagnosed with Infectious Mononucleosis. Selcuk Med J 2020;36(3): 184-191
Disclosure: None of the authors has a financial interest in any of the products, devices, or drugs mentioned in this article. The research was not sponsored by an outside organization. All authors have agreed to allow full access to the primary data and to allow the journal to review the data if requested. 


\section{INTRODUCTION}

Epstein-Barr virus (EBV) is a DNA virus that belongs to the gammaherpesviridae subfamily among herpes viruses. The EBV can lead to the development of many benign or malignant diseases such as chronic active EBV infections, especially infectious mononucleosis (EMN), Burkitt's lymphoma, nasopharyngeal carcinoma (1-4).

Epstein-Barr virus is transmitted through close contact and the use of common items. The virus settles in lymphoepithelial cells and B lymphocytes located in the oral cavity. First, it holds the tonsils and settles. After the virus enters the cell, EBV nuclear antigens become detectable in the cell nucleus. Excipients formed by nuclear antigens allow the synthesis of latent membrane proteins 1 (LPM-1) and 2 (LMP-2). Then copy cells containing the genetic elements of the virus are formed and the virus is latently located in $B$ lymphocytes. In these hosts, EBV is reactive in case of weakening of the immune system $(1,2,5-7)$.

A total of $90-95 \%$ of children are infected with EBV in the first six years of age. Seropositivity can be detected in approximately $90 \%$ of adults. In societies with low socioeconomic status, EBV infections can occur at an earlier age. Infectious mononucleosis can be asymptomatic in childhood, and it may be seen in some children and adults with a table containing the symptoms and signs of sore throat, lymphadenopathy (LAP), fever, pharyngitis, weakness and splenomegaly. In EBV infection, a similar clinical picture can be seen with some infections such as cytomegalovirus (CMV) and rubella. Therefore, the differential diagnosis should be made. In addition, some serious complications such as respiratory obstruction, intrasplenic hemorrhage, myocarditis and anemia may develop in EBV infections. Therefore, the diagnosis of EBV infection is important (1,2,8-11).

Many serological tests such as enzyme immunoassay (EIA), indirect immunofluorescence (IFA), enzyme labeled fluorescent test (ELFA), microparticle-based immunassay (MPTI), complement junction test, and immunoblot (IB) are used in the diagnosis of EBV infection. There is no method set as the gold standard in these tests. These methods have advantages and disadvantages against each other. This situation may cause some problems in the diagnosis of EBV $(5,8,12)$.

In our study, it was aimed to examine the clinical presentation of acut EBV infections by age and highrisk age groups among children.

\section{PATIENTS AND METHODS}

This study was approved by the local ethics committee and planned retrospectively.

\section{Patients and Tests}

A total of 337 pediatric patients who were admitted to our tertiary hospital between June 2013 and February 2020 and suspected to have EMN were included in the study. EBV VCA IgM, IgG, and EBNA IgG antibodies were detected by working with ELISA method (quantitative microplate ELISA, Euroimmun®, Germany) in accordance with the firm's recommendations. The records were examined through the hospital information system and the results were evaluated retrospectively. The sensitivity of the streptococcus test was $86 \%$ and the specificity was $95 \%$. Analytical sensitivity and specificity of EBV VCA IgM and IgG antibodies were $97 \%$ and $94 \%$, respectively.

Patients with EBV VCA IgM positivity ( \pm antiVCAIgG positive) and EBNA IgG negativity were considered as acute infections. The cases were not included in the study if the EBNA was treated with IgG positivity because of immune failure and malignancy, or if they had incomplete data and no regular control. Reactivity, reinfection, primary infection cases, those with immunodeficiency and cancer patients were excluded from the study. The clinical status of the patients with false IgM positivity, prolonged IgM response or false IgM negativity, and IgG positization, which was checked and monitored within 3-4 weeks, were decided. Patients who were not diagnosed with EBV acute infection were excluded from the study. During this period, patients were subjected to an EBNA IgG test $(12,13)$. Patients who were not considered other viral or bacterial agents in the differential diagnosis were evaluated as EBV infection.

\section{Pre-diagnosis-diagnosis Algorithm}

In addition to the complaints such as sore throat, fever, malaise, lymphadenopathy, pharyngitis, organomegaly, skin rash, fever of unknown cause, viral exanthem, antibody test results were evaluated together with the work. In addition to clinical and other laboratory findings compatible with EMN, EBV VCA IgM positive ( \pm antiVCA IgG positive) and EBNA IgG negative patients were considered acute EBV infections.

\section{Statistical analysis}

All statistical analyzes in the study were done using SPSS 25.0 software (IBM SPSS, Chicago, IL, USA). Descriptive data are given as numbers and percentages. In terms of categorical variables, 
comparisons between groups were made with Pearson's Chi Square test and Fisher's Exact Test. Whether continuous variables are suitable for normal distribution was confirmed by the Kolmogorov-Smirnov Test. The differences between the groups in terms of continuous variables were made using Student's $t$ Test and the comparison of mean values between multiple groups by variance analysis. The results were evaluated within the $95 \%$ confidence interval and $p$ $<0.05$ values were considered significant. Bonferroni correction was made where appropriate.

\section{RESULTS}

The mean age of the patients included in the study was $5.1 \pm 3.4$ years (range: $1-16$ years). $77(22.8 \%)$ of the patients were $0-2$ years old, 145 (43.0\%) were 3-5 years old, 100 (29.7\%) were 6-12 years old, 15 $(4.5 \%)$ were 12 years old and above. (Figure 1). In the study, all 0-2 year-old children were over one year old. The most common signs or symptoms in children diagnosed with acute EBV infection were lymphadenopathy (59.6\%), lymphocytosis (45.1\%), fever $(40.9 \%)$, swelling in the throat $(39.2 \%)$ and pharyngitis (30.0\%) (Table 1). The distribution of signs and symptoms by age groups are shown in Table 1 .

The distribution of cases by seasons and months was in the range of $21.4-30.6 \%$ (Figure 2). It was determined that the cases increased in years and the most cases were seen in 2019 (79 cases, 23.4\%) (Figure 3). No significant difference was found in terms of the number of cases in age groups by years $(p=0.558)$. It was observed that the time from the start of complaints to the hospital was increased in direct proportion with the age groups (Figure 3).

Mean values of laboratory findings are shown in Table 2. There was no significant difference between those who used and did not use antibiotics in terms of rash $(p=0.462)$. No significant difference was found between the age groups in terms of rash incidence $(p=0.327)$. The incidence of fever was significantly higher between the ages of 3-5 compared to other age groups $(p=0.003)$, there was no significant difference between the age groups in terms of the incidence of other signs and symptoms ( $p>0.005$ for each according to the Bonferroni correction).

\section{DISCUSSION}

In infections caused by Epstein-Barr virus, the

Table 1. Distribution of signs and symptoms by age groups.

\begin{tabular}{|c|c|c|c|c|c|c|c|}
\hline \multirow{2}{*}{$\begin{array}{l}\text { Symptoms } \\
\text { and findings }\end{array}$} & \multicolumn{2}{|c|}{ Total } & \multirow[b]{2}{*}{$\begin{array}{c}0-2 \text { years } \\
(n=77)(\%)\end{array}$} & \multicolumn{3}{|c|}{ Age groups } & \multirow[b]{2}{*}{$p^{*}$} \\
\hline & $\mathbf{n}$ & $\%$ & & $\begin{array}{c}3-5 \text { years } \\
(n=145)(\%)\end{array}$ & $\begin{array}{l}6-12 \text { years } \\
(n=100)(\%)\end{array}$ & $\begin{array}{l}>12 \text { years } \\
(n=15)(\%)\end{array}$ & \\
\hline$\overline{\mathrm{LAP}}$ & 201 & 59.6 & 55.8 & 55.9 & 71.0 & 40.0 & 0.028 \\
\hline Lymphocytosis & 152 & 45.1 & 56.0 & 45.0 & 41.0 & 20.0 & 0.109 \\
\hline Fever & 138 & 40.9 & 44.2 & 49.7 & 29.0 & 20.0 & 0.004 \\
\hline Swelling in the throat & 132 & 39.2 & 36.4 & 36.6 & 48.0 & 20.0 & 0.1 \\
\hline Pharyngitis & 101 & 30.0 & 41.6 & 25.5 & 29.0 & 20.0 & 0.07 \\
\hline Leukocytosis & 98 & 28.2 & 27.7 & 32.0 & 25.9 & 0 & 0.203 \\
\hline Exudative tonsillitis & 78 & 23.1 & 29.9 & 20.0 & 23.0 & 20.0 & 0.416 \\
\hline AST height & 78 & 56.1 & 17.0 & 26.0 & 25.0 & 13.0 & 0.321 \\
\hline Anemia & 77 & 22.9 & 53.8 & 27.0 & 12.3 & 22.2 & $<0.001$ \\
\hline Splenomegaly & 72 & 21.4 & 19.5 & 23.4 & 20.0 & 20.0 & 0.881 \\
\hline ALT height & 66 & 41.5 & 12.0 & 17.0 & 30.0 & 13.0 & 0.061 \\
\hline Sore throat & 60 & 17.8 & 11.7 & 16.6 & 21.0 & 40.0 & 0.049 \\
\hline Hepatomegaly & 43 & 12.8 & 11.7 & 15.9 & 9.0 & 13.3 & 0.456 \\
\hline Thrombocytopenia & 36 & 10.7 & 13.0 & 11.0 & 8.0 & 13.0 & 0.636 \\
\hline Hepatosplenomegaly & 26 & 7.7 & 7.8 & 7.6 & 8.0 & 6.7 & 0.998 \\
\hline Abdominal pain & 24 & 7.1 & 2.6 & 7.6 & 8.0 & 20.0 & 0.098 \\
\hline Skin rash & 23 & 6.8 & 9.1 & 8.3 & 4.0 & 0 & 0.327 \\
\hline Runny nose & 22 & 6.5 & 10.4 & 4.8 & 5.0 & 13.3 & 0.252 \\
\hline Lymphopenia & 11 & 3.3 & 1.0 & 3.0 & 5.0 & 7.0 & 0.109 \\
\hline Otalgia & 8 & 2.4 & 0 & 4.1 & 2.0 & 0 & 0.236 \\
\hline Diarrhea & 8 & 2.4 & 2.6 & 2.8 & 2.0 & 0 & 0.911 \\
\hline Leukopenia & 6 & 1.8 & 1.5 & 3.3 & 0 & 0 & \\
\hline
\end{tabular}

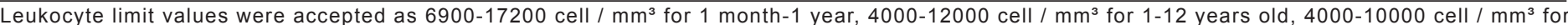
12 years old (11). Limit values for hemoglobin (anemia) were accepted as $11 \mathrm{~g} / \mathrm{dl}$ for 6 months-6 years old and $11.5 \mathrm{~g} / \mathrm{dl}$ for 6-18 years old (11). LAP: Lymphadenopathy, AST: Aspartate amino transferase, ALT: Alanine amino transferase. ${ }^{*} p<0.008$ was considered significant according to the Bonerroni correction. 


\section{Patients number}

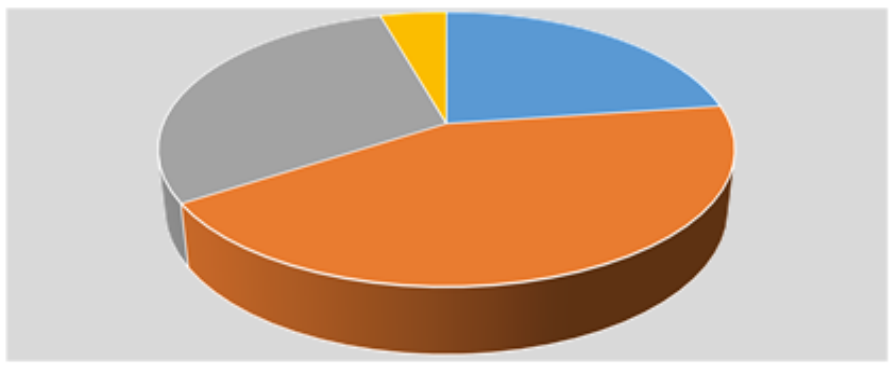

$=0-2$ years* $\quad$ " 3-5 years $\quad$ - 6-12 years $=>12$ years

Figure 1. Distribution of age groups. ${ }^{*}$ All patients in this group are over one year old.

clinical picture can be confused with upper respiratory infections. Accurate and early diagnosis of EBV infections is important to prevent complications that may develop $(2,5,8)$. In our study, the clinical presentation of EBV infections by age and high-risk age groups among children were examined to help

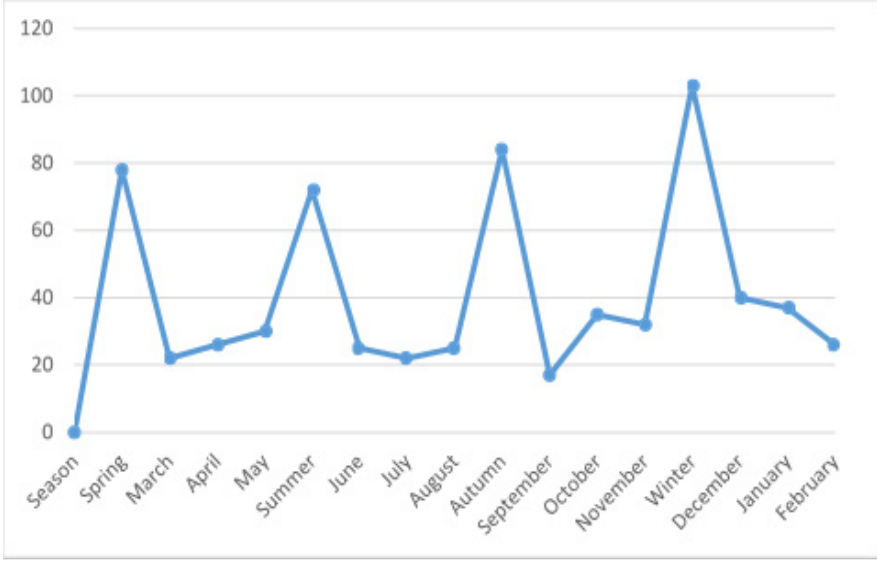

Figure 2. Distribution of cases according to seasons.

the doctors to true determine the upper respiratory infections.

It has been reported that the age groups most frequently affected by EBV infection in childhood differ among societies between the ages of 1-6 (11-19). In our study, it was observed that the most common 3-5 years old children $(43.0 \%)$ had primary EBV infection.

Table 2. Mean values of laboratory findings.

\begin{tabular}{|c|c|c|c|c|}
\hline & Mean & SD & Minimum & Maximum \\
\hline Sedimentation (1 hour) & 24.5 & 20.9 & 1.0 & 110.0 \\
\hline $\mathrm{CRP}(\mathrm{mg} / \mathrm{L})$ & 29.6 & 59.8 & 0.2 & 413.3 \\
\hline $\mathrm{ALT}(\mathrm{IU} / \mathrm{L})$ & 84.7 & 177.1 & 7.3 & 1356.5 \\
\hline AST (IU/L) & 79.6 & 136.8 & 14.4 & 1002.9 \\
\hline $\mathrm{RBC}\left(10^{6} / \mathrm{mL}\right)$ & 4.6 & 0.5 & 2.8 & 6.6 \\
\hline Neutrophils $\left(10^{9} / \mathrm{L}\right)$ & 4.4 & 3.6 & 0.0 & 21.6 \\
\hline$\%$ Neutrophils & 36.2 & 19.5 & 0.0 & 85.7 \\
\hline Het $(\%)$ & 34.3 & 3.6 & 19.1 & 48.5 \\
\hline $\mathrm{Hb}(\mathrm{g} / \mathrm{dL})$ & 11.6 & 1.3 & 6.0 & 16.1 \\
\hline WBC $\left(10^{3} / \mathrm{mL}\right)$ & 12.6 & 6.3 & 0.9 & 47.4 \\
\hline Lypmhocytes (10\%/L) & 6.3 & 4.6 & 0.0 & 35.0 \\
\hline $\mathrm{MCH}(\mathrm{pg} / \mathrm{cell})$ & 25.2 & 2.3 & 15.6 & 30.0 \\
\hline $\mathrm{MCHC}(\% \mathrm{Hb} /$ cell $)$ & 33.8 & 1.4 & 28.4 & 37.2 \\
\hline $\operatorname{MCV}\left(\mathrm{mm}^{3}\right)$ & 74.5 & 5.4 & 50.5 & 90.5 \\
\hline Monocytes $\left(10^{9} / \mathrm{L}\right)$ & 1.3 & 1.0 & 0.0 & 7.8 \\
\hline$\%$ Monocyte & 10.8 & 4.7 & 0.0 & 41.1 \\
\hline $\operatorname{MPV}(f L)$ & 9.4 & 1.0 & 0.0 & 11.9 \\
\hline PDW (fL) & 10.5 & 1.9 & 0.0 & 17.3 \\
\hline Platelet $\left(10^{3} / \mathrm{mL}\right)$ & 262.5 & 106.2 & 5.0 & 694.0 \\
\hline \% Lypmhocyte & 50.6 & 19.6 & 0.0 & 88.7 \\
\hline Eosinophils $\left(10^{9} / \mathrm{L}\right)$ & 0.1 & 0.2 & 0.0 & 2.0 \\
\hline$\%$ Eosinophils & 1.3 & 2.0 & 0.0 & 18.2 \\
\hline Basophils (10\%/L) & 0.1 & 0.2 & 0.0 & 1.2 \\
\hline$\%$ Basophils & 1.0 & 1.1 & 0.0 & 6.7 \\
\hline
\end{tabular}

RBC: Red blood cells, Hb: Hemoglobin, Hct: Hematocrit, MCV: Mean corpuscular volume, MCH: Mean corpuscular hemoglobin, MCHC: Mean corpuscular hemoglobin concentration, WBC: White Blood cells, MPV: Mean platelet volume, SD: Standard deviation. 


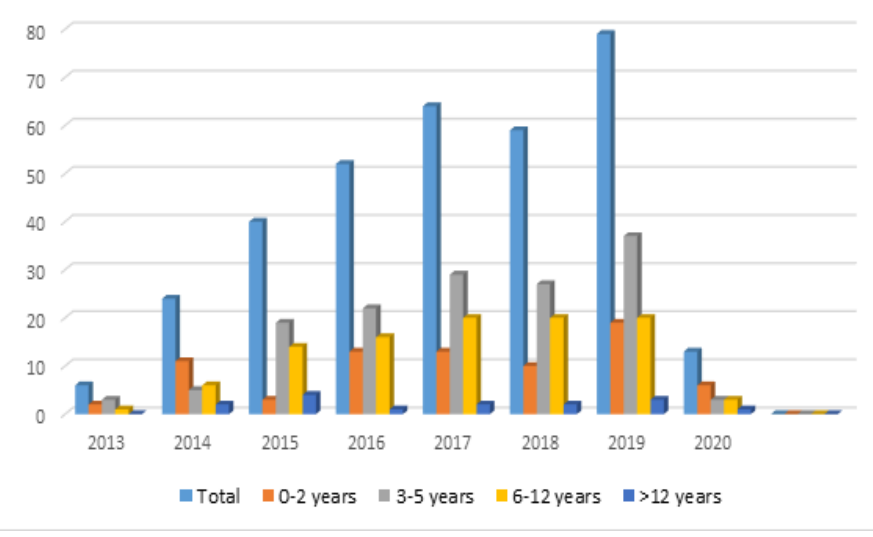

Figure 3. Distribution of case numbers by age groups and years. $p=0.558$

0-2 age group constituted $22.8 \%$ of the patients in our study. These data show that EBV infection is common under the age of six, and EBV infection can be seen at a significant rate under the age of two.

It has been stated that some signs and symptoms may vary depending on the age of children with acute EBV infection $(2,5,11)$. Cengiz et al. (11) reported that no finding in their study was associated with age. Son et al. (20) also reported that the signs and symptoms were not related to age groups. Son et al. (20) complaints of headache, Topp et al. (21) reported that headache, sore throat, abdominal pain, muscle and joint pain and nausea complaints were significantly lower under the age of four, but it should not be overlooked that some complaints cannot be expressed by the child at a young age. Gao et al. (22) found the rash rate significantly higher in children under one year old, but stated that this may be related to antibiotic use. In our study, the rate of fever was found to be significantly higher in the 3-5 age group compared to other age groups. However, the incidence of all other signs and symptoms was similar between age groups. These data show that the symptoms of acute EBV infection in childhood do not change with age in general.

It has been reported that maternal antibodies passed through the mother protect the child against EBV infection in the first months of life, therefore, EBV infection is very rare under one year $(11,17)$. Cengiz et al. (11) in their study, only one patient, Gao et al. (22) reported that six patients were under one year old. Zhang et al. (19) did not detect patients under one year in their study. In our study, no acute EBV infection was detected in any child under one year of age. These data support the information that EBV does not have an important role in differential diagnosis in children under one year old with symptoms of upper respiratory tract infection.

It has been reported that acute EBV infection may affect the younger age group over the years, but there is not enough data for this yet $(11,16)$. Devkota et al. (16) found that the proportion of children under four years of age in EBV cases increased significantly between 2014-2017. In our study, there was no significant change in the number of cases in age groups between 2013 and 2020. Although this data covers only an eight-year period, it currently supports that there is insufficient evidence to say that younger children are increasingly experiencing EBV infection.

The most common findings in acute EBV infection have been reported to be fever, lymphadenopathy and tonsillopharyngitis $(1,2,5)$. Cengiz et al. (11) reported that the most common signs and symptoms in pediatric patients were lymphadenopathy $(79.5 \%)$, tonsillopharyngitis $(72.7 \%)$, swelling in the throat $(68.1 \%)$, enlargement in tonsils $(47.7 \%)$ and fever $(43.1 \%)$. Vural et al. (14) stated that the most common signs and symptoms in their study were lymphadenopathy $(77.5 \%)$, swelling of the neck or throat $(72.4 \%)$, tonsillar growth $(60.3 \%)$, fever $(51.7 \%)$ and sore throat $(44.8 \%)$. Kılıç et al. (23) reported the most common symptoms as fever $(86.5 \%)$ and splenomegaly (47.9\%). Çağlar et al. (15) found the most common symptoms as fever (92.4\%), lymphadenopathy $(81.8 \%$ and swelling in the neck (63.6\%). González-Saldaña et al. (24) were the most common findings for lymphadenopathy (89.5\%) and fever $(79.7 \%)$. In our study, the most common findings were lymphadenopathy $(59.6 \%)$, lymphocytosis $(45.1 \%)$, fever $(40.9 \%)$, swelling in the throat $(39.2 \%)$, and pharyngitis (30.0\%). These data were significantly diagnosed in children with EBV infection. It shows that there are supporting findings, fever, lymph nodes in the throat or swelling of tonsils and tonsillopharyngitis are generally expected signs and symptoms. These findings show that the symptoms of EBV infection in children are similar to those in adults.

It has been reported that more than $80 \%$ of children diagnosed with acute EBV infection have fever, and in these cases the fever can last up to seven days $(17,18)$. However, Cengiz et al. (11) reported that only $43.1 \%$ of their cases had fever, and this low rate was attributed to the long Mean application period (7.3 days) in their studies. Vural et al. (14) rate of fever 
$51.7 \%$, Bilal et al. (25) as 69.2\%, and GonzálezSaldaña et al. (24) reported as $79.7 \%$. In our study, the rate of cases with fever was found as low as $40.9 \%$. In our study, the mean time between the onset of complaints and admission to the hospital was 4.4 \pm 3.9 days. This period may have caused the febrile period to be ended in some patients and therefore our rate of febrile cases was found to be relatively low.

Children with upper respiratory tract infections often have elevated leukocyte levels. In the case of bacterial infection, an increase in neutrophil rate with leukocytosis is expected, and in viral infections, more often lymphocytosis is expected. Although the lymphocyte count may be normal or slightly low in the early period of the disease, the number of lymphocytes increases from the second week $(2,5,11,14)$. Cengiz et al. (11) found the rate of leukocytosis as $29.5 \%$ in children with acute EBV infection. However, they reported that $44.7 \%$ of patients had lymphocytosis and $2.2 \%$ had leukopenia. Vural et al. (14) reported leukocytosis in $34.4 \%$ of their patients, leukopenia in $2.2 \%$, and lymphocytosis in $38.6 \%$. Kılıç et al. (23) found the lymphocytosis rate as $40.2 \%$ and the leukopenia rate as 5.6\%. Çağlar et al. (15) reported leukocytosis rate as $65.1 \%$ and lymphocytosis rate as $42.4 \%$. Abdel-Aziz et al. (26) in $83.3 \%$ of patients, González-Saldaña et al. (24) reported that $41.7 \%$ had lymphocytosis. In our study, the leukocytosis rate was $28.2 \%$, and the leukopenia rate was $1.8 \%$. In our study, lymphocytosis rate was found as $45.1 \%$ and lymphopenia rate as $3.3 \%$. These data show that lymphocytosis frequently accompanies the EBV picture and leukocytosis finding in EBV infection should be expected in $25-30 \%$ of patients. However, in children with leukopenia and lymphopenia, EBV diagnosis should not be ignored.

Anemia is frequently seen in acute EBV infection in children $(11,17,18)$. Cengiz et al. (11) reported anemia rate as $29.5 \%$ in children with acute EBV infection in their study. Vural et al. (14) reported that $20.6 \%$ of their cases had anemia. In our study, the rate of anemia was found to be $22.9 \%$. In our study, it was also observed that the rate of anemia in the 0-2 age group was above $50 \%$. These data show that anemia table may be more frequent in pediatric patients with suspected EBV, especially in younger age groups, and the diagnosis of EBV infection should be taken into account in children with an upper respiratory tract infection with anemia.

It has been reported that thrombocytopenia in infectious mononucleosis is caused by platelet antibodies in the IgG structure formed against IgM $(2,14)$. Chan et al. (17) found thrombocytopenia in $21 \%$ of the children with acute EBV infection. Cengiz et al. (11) reported that $11.3 \%$ of their cases had thrombocytopenia. Vural et al. (14) found thrombocytopenia in $8.6 \%$ of their cases. In our study, the rate of thrombocytopenia was found to be $10.7 \%$, and there was no significant difference between age groups. These data indicate that low rates of thrombocytopenia can be seen in cases of EBV infection in childhood.

It has been reported that more than $60 \%$ of children who have acute EBV infection can experience typical upper respiratory tract symptoms such as sore throat and runny nose (17). Cengiz et al. (11) reported that these symptoms were observed in $45 \%$ of their patients. In our study, $17.8 \%$ of the patients had sore throat, $6.5 \%$ had runny nose and/or congestion. We can attribute the low rate of these rates to the fact that very young children may not be able to describe the sore throat. These data show that the rate of diagnosis of EBV infection is not low in patients with typical upper respiratory infection complaints.

Acute EBV infection can involve the liver and spleen in many pediatric patients $(5,11,17)$. Cengiz et al. (11) detected splenomegaly in $34 \%$ of pediatric patients, hepatomegaly in $25 \%$, and hepatosplenomegaly in $22.7 \%$. In their study, they determined that $90.4 \%$ of cases had AST elevation and $61.9 \%$ had ALT elevation. Vural et al. (14) reported ALT in $56.1 \%$ of patients and AST in $75.6 \%$ of their patients. Kılıç et al. (23) found the rate of splenomegaly to be $47.9 \%$ and the rate of hepatomegaly to $21.4 \%$. Çağlar et al. (15) reported the rate of splenomegaly as $42.4 \%$ and the rate of hepatomegaly as $30.3 \%$. Abdel-Aziz et al. (26) reported that liver enzymes were elevated in $79.1 \%$ of their patients. In our study, splenomegaly was found in $21.4 \%$ of patients, hepatomegaly was found in $12.8 \%$, and the rate of hepatosplenomegaly was $7.7 \%$. In our study, AST elevation was found in $56.1 \%$ of patients and ALT in $41.5 \%$ of patients. These findings show that the EBV table may affect the liver and spleen in children, and the diagnosis of EBV should be taken into consideration in the upper respiratory tract infection table with hepatomegaly and splenomegaly or impaired liver function tests.

It has been reported that maculopapular skin rash can be seen especially in acute EBV infection in children $(17,18)$. Cengiz et al. (11) reported that rash was observed in $22.7 \%$ of the cases, and the rate of rash was higher under the age of four. Vural et al. 
(14) reported a rash in $17.2 \%$ of their cases. Kılıç et al. (23) found the rash rate to be $10.3 \%$. Chan et al. (17) statistically associated rash with antibiotic use in these cases. Çağlar et al. (15) reported the rash rate as $27.4 \%$ but could not associate this rate with antibiotic use. Gao et al. (22) also detected rash in $14.8 \%$ of their patients, and stated that $66 \%$ of these patients used antibiotics. In our study, no significant difference was found between the users of antibiotics and those who did not use them, and the age groups in terms of rash rates, but none of the children over 12 years old had rashes. These data show that children who have acute EBV infection at a younger age may experience skin rash, in some cases this may be due to antibiotic use, and the likelihood of rash decreases dramatically with age.

It has been reported that ear complaints can rarely be seen in children with acute EBV infection (11). Cengiz et al. (11) could not detect otitis media in their cases. In our study, ear pain was observed in only $2.4 \%$ of the patients. These data show that EBV and ear complaints are not significantly related in children. Cengiz et al. (11), Chan et al. (17) and Cheng et al. (18) reported that the frequency of acute EBV infection in children did not change significantly according to the seasons in their studies. Son et al. (19) reported that although their cases were more common in April, May, September and October, there was no seasonal difference. Shi et al. (27) reported that the number of cases increased over the years, but the seasonal distribution did not differ. Zhang et al. (19) stated that the cases were seen more frequently in the summer and autumn months. In our study, the months with the most frequent cases were determined as December, January and October, but no difference was found between the seasons in terms of the number of cases. These data mean that acute EBV infection can be seen in every period of the year in childhood and this infection does not show seasonal characteristics.

In our study, group A beta hemolytic streptococcus test was positive in ten patients. This finding shows that the detection of this bacterium in pediatric patients presenting with the symptoms and findings of upper respiratory tract infection cannot rule out the diagnosis of infectious mononuclease, and the necessary tests should be performed in these patients for EBV.

There were some limitations in our study. Since our study was retrospective, patients could not be examined for a long time. Therefore, the recovery time of patients and the normalization of growth in liver and spleen could not be determined. Also, it was not evaluated whether complications developed in the long-term.

Our study data show that in acute EBV infection, there is no difference between childhood age groups in terms of signs and symptoms, the number of cases does not differ seasonally, the number of cases is increasing slightly over the years, especially in children with lymphadenopathy, splenomegaly and hepatomegaly, it is necessary to doubt EBV infection.

Conflict of interest: Authors declare that there is no conflict of interest between the authors of the article.

Financial conflict of interest: Authors declare that they did not receive any financial support in this study.

Address correspondence to: Hayrettin Temel, Istanbul Medipol University, Faculty of Medicine, Department of Pediatrics, 34214, Istanbul, Turkey

e-mail: hayrettintemel@hotmail.com

Phone: +90 (216) 6815148

\section{REFERENCES}

1. Zamora MR. DNA viruses (CMV, EBV, and the herpesviruses). Semin Respir Crit Care Med 2011;32(4):454-70.

2. Niller $\mathrm{HH}$, Bauer $\mathrm{G}$. Epstein-barr virus: Clinical diagnostics. Methods Mol Biol 2017;1532:33-55.

3. Farrell PJ. Epstein-barr virus and cancer. Annu Rev Pathol 2019;14:29-53.

4. Ozoya OO, Sokol L, Dalia S. EBV-Related malignancies, outcomes and novel prevention strategies. Infect Disord Drug Targets 2016;16(1):4-21.

5. Smatti MK, Al-Sadeq DW, Ali NH, et al. Epstein-barr virus epidemiology, serology, and genetic variability of LMPoncogene among healthy population: An update. Front Oncol 2018;8:211.

6. Ascherio A, Munger KL. EBV and autoimmunity. Curr Top Microbiol Immunol 2015;390(Pt 1):365-85.

7. Long HM, Taylor GS, Rickinson AB. Immune defence against EBV and EBV-associated disease. Curr Opin Immunol 2011;23(2):258-64.

8. AbuSalah MAH, Gan SH, Al-Hatamleh MAI, et al. Recent advances in diagnostic approaches for epstein-barr virus pathogens. 2020;9(3).

9. Nowalk A, Green M. Epstein-barr virus. Microbiol Spectr 2016;4(3).

10. Kerr JR. Epstein-barr virus (EBV) reactivation and therapeutic inhibitors. J Clin Pathol 2019;72(10):651-8.

11. Cengiz AB, Cultu-Kantaroğlu $O$, Seçmeer $G$, et al. Infectious mononucleosis in Turkish children. Turk J Pediatr 2010;52(3):245-54.

12. Feyzioglu B, Özdemir M, Baykan M, et al. Comparative evaluation of indirect immunofluorescence assay and ELISA methods for the diagnosis of epstein-barr virus infection. Selçuk Üniv Tıp Derg 2011;27(2):77-82.

13. Obel N, Høier-Madsen M, Kangro H. Serological and clinical findings in patients with serological evidence of reactivated epstein-barr virus infection. APMIS 1996;104(6):424-8.

14. Vural O, Metin Akcan Ö, Arslan D, et al. Çocuk enfeksiyon 
hastalıkları polikliniğine başvuran enfeksiyöz mononükleoz tanısı alan hastaların değerlendirilmesi. Çocuk Dergisi 2018;18(1):19-23.

15. Çağlar I, Topal S, Çokboz $M$, et al. Clinical features and laboratory findings in children hospitalized with acute epsteinbarr virus infection: A crosssectional study in a tertiary care hospital. Turk J Pediatr 2019;61(3):368-73.

16. Devkota K, He M, Liu MY, et al. Increasing epstein-barr virus infection in chinese children: A single institutional based retrospective study. Version 2. F1000Res 20187 [revised 2019 15];7:1211.

17. Chan $\mathrm{CW}$, Chiang $\mathrm{AK}$, Chan $\mathrm{KH}$, et al. Epstein-barr virusassociated infectious mononucleosis in chinese children. Pediatr Infect Dis J 2003;22: 974-8.

18. Cheng CC, Chang LY, Shao PL, et al. Clinical manifestations and quantitative analysis of virus load in Taiwanese children with Epstein-Barr virus-associated infectious mononucleosis. J Microbiol Immunol Infect 2007;40:216-21.

19. Zhang $Y$, Zhao $Y$, Jiang $Y$, et al. Effects of epstein-barr virus infection on liver function in children. J Infect Public Health 2020;13(2):260-5.

20. Son KH, Shin MY. Clinical features of epstein-barr virusassociated infectious mononucleosis in hospitalized Korean children. Korean J Pediatr 2011;54(10):409-13.

21. Topp SK, Rosenfeldt V, Vestergaard H, et al. Clinical characteristics and laboratory findings in danish children hospitalized with primary epstein-barr virus infection. Infect Dis (Lond) 2015;47(12):908-14.
22. Gao LW, Xie ZD, Liu YY, et al. Epidemiologic and clinical characteristics of infectious mononucleosis associated with epstein-barr virus infection in children in Beijing, China. World J Pediatr 2011;7(1):45-9.

23. Kılıç $A$, Yıldız İ, Beka $\mathrm{H}$, et al. Çocuklarda farklı klinik tablolarla enfeksiyöz mononükleoz: 369 vakanın geriye dönük incelenmesi. Türk Ped Arş 2012;47:189-92.

24. González Saldaña N, Monroy Colín VA, Piña Ruiz G, et al. Clinical and laboratory characteristics of infectious mononucleosis by epstein-barr virus in mexican children. BMC Res Notes 2012;5:361.

25. Bilal JA. Prevalence and clinical characteristics of primary epstein-barr virus infection among children presented with cervical lymphadenopathy. J Clin Diagn Res 2015;9(7):SC0810.

26. Abdel-Aziz M, El-Hoshy $\mathrm{H}$, Rashed $\mathrm{M}$, et al. Epstein-barr virus infection as a cause of cervical lymphadenopathy in children. Int J Pediatr Otorhinolaryngol 2011;75(4):564-7.

27. Shi J, Ma W, Li W. Epidemiologic features of children with epstein-barr virus associated diseases in Hangzhou, China. J Med Virol 2020;92:1277-82. 